\author{
Richard Sharpley \\ University of Central Lancashire, UK \\ Innocent Gahigana \\ Rwanda Tourism University College, Rwanda \\ UDC: 338.48-6:343.285(675.98) ; 341.485(675.98)"1994"
}

\title{
TOURIST EXPERIENCES OF GENOCIDE SITES: THE CASE OF RWANDA
}

\begin{abstract}
Dark tourism is not a new phenomenon. As long as people have been able to travel they have visited places associated with death, disaster and suffering. However, not only has the provision and consumption of dark tourism experiences become increasingly evident in recent years; so too has the academic study of the phenomenon. Nevertheless, despite the increasing attention paid to the subject, understanding of dark tourism remains relatively limited and theoretically fragile whilst, specifically, the significance of the consumption of or demand for dark tourism has enjoyed limited academic scrutiny. This is particularly the case with so-called 'genocide tourism' (visiting places of, or associated with, genocide), a form of dark tourism that is increasingly in evidence but the consumption of which is often misunderstood and, typically, considered to display voyeuristic tendencies on the part of tourists. Focusing on the Rwandan genocide, this paper addresses this issue. Locating genocide tourism within
\end{abstract}

\section{Introduction}

Twenty years ago, on 6 April 1994, the small East African state of Rwanda witnessed the beginning of 'one of the most coldblooded attempts to annihilate a people' in recent history (Cook, 2006; Friedrich \& Johnston, 2013). Triggered by the death of the country's then President, Juvenal Habyarimana, when the aeroplane in which he was travelling was shot down as it approached Kigali airport, the genocide lasted the context of dark tourism more generally, it reviews briefly how the Rwandan genocide is presented / memorialised before considering research into how tourists experience genocide memorial sites in Rwanda. Specifically, building on an earlier study that explored visitor experiences of genocide sites in Rwanda as described in travel blogs, it considers the results of an exploratory survey into tourists' experiences of the Kigali Genocide Memorial, the country's principal memorial site. The results indicate unequivocally that tourists undertake their visits with positive, meaningful intent (albeit with trepidation) and that, almost without exception, find it a challenging, powerfully emotional yet, ultimately, rewarding experience in that they begin to grasp the horror and suffering of the genocide and, indeed, leave with the desire to learn more about it.

Key words: dark tourism, genocide tourism, Rwanda, tourist experience

100 days and although the precise number remains unknown, more than a million people lost their lives (KGM, 2004: 22). The great majority of victims were Tutsis who at that time collectively represented just $14 \%$ of the country's population of seven million, whilst the perpetrators were mostly Hutus (Alluri, 2009; Melvern, 2009; Prunier, 2008). The violence came to an end only when the Tutsi-led Rwandan Patriotic Front (RPF), led by the country's current President, Paul Kagame, captured Kigali, the capital, and 
established a multi-ethnic government. As a result of the genocide, approximately 75\% of the Tutsi minority had been killed, more than 300,000 children were orphaned and some two million Hutus, fearing retaliation, fled into neighbouring countries.

Since then, Rwanda has remained relatively peaceful and has made significant developmental progress. The economy has grown at an annual average rate of $7 \%-8 \%$, developmental targets for education and health are being met whilst the incidence of poverty has been reduced (AEO, 2014). However, $44.9 \%$ of the population still live below the poverty line and small-scale subsistence farming remains the principal economic activity, accounting for $73 \%$ of employment but $36 \%$ of output. Coffee and tea have long been important export products but, significantly, since 2011 tourism has become the top source of foreign exchange earnings. Prior to the events of 1994 Rwanda had been an established international tourist destination, but the sector was devastated by the genocide. However, in the years that followed tourism grew rapidly; latest available data suggest that, in 2010, the country attracted 660,000 international visitors who generated some US\$200 million in revenues, although it must be noted that $80 \%$ were from neighbouring countries whilst just 38,136 , or $5.8 \%$, were non-African leisure visitors ( $\mathrm{RDBa}, 2014)$. For the latter, the principal attraction is the country's wildlife in general and, as prior to the genocide, the mountain gorillas in particular.

However, the 1994 genocide itself has, in a sense, become a tourist attraction. That is, not only is contemporary Rwanda defined by the genocide and its aftermath, remaining as it does in the living memory of many Rwandans, but a number of the four hundred or so genocide memorials around the country have become tourist sites. Standing in stark contrast to the vision of the country described by the national tourism authority as 'a green undulating landscape of hills, gardens and tea plantations' and 'the Land of a Thousand Hills (RDBb 2014), these memorials, often located on the site of massacres and mass graves, not only reflect survivors' determination that the atrocities of 1994 should not be forgotten but also act as a 'constant reminder of the tragic events which transpired at countless sites of violence throughout the country' (Friedrich \& Johnston, 2013).

At the same time, these sites have become 'dark' tourism attractions. They are frequently listed in contemporary tourist guides along with the country's national parks and other natural and cultural sites as 'things to see' and many local tour operators include a visit to genocide memorials in their tours (Schaller, 2007). In particular, the Kigali Genocide Memorial, the country's principal memorial to the events of 1994 and the focus of the research in this paper, is not only an established feature of Kigali city tours but, according to Friedrich \& Johnston (2013), attracted more than 42,000 international visitors in 2011, more than double the number of local visitors. It has, in effect, become a 'must see' for visitors to Rwanda. However, although it undoubtedly represents the tragedy of the genocide and, semiotically, is symbolic of contemporary Rwanda, the reasons for its popularity amongst tourists remain unclear.

Indeed, significant debate surrounds the memorialisation and representation of genocide, both in Rwanda and elsewhere, for tourist consumption or the development of what some refer to more generally as 'genocide tourism' (Beech, 2009). More specifically, genocide memorial sites (and other sites memorialising death and suffering on a large scale) fulfil a variety of vital purposes, including not only remembrance but also education and, in the case of genocide, war and other violent conflict, reconciliation (Cohen 2011; Sharpley, 2009a; Williams, 2004; 2007). However, the promotion, exploitation and commoditisation of geno- 
cide sites / memorials as tourist attractions is controversial both from an ethical point of view and, in particular, with respect to tourists' motivations. As Schaller (2007: 514) observes, 'it is, after all, the great demand for trips to former concentration camps and killing fields that makes genocide tourism possible in the first place'. Many, including Schaller, consider genocide tourism to be little more than voyeurism, a label applied by some to dark tourism more generally (Buda \& McIntosh, 2013; Lisle, 2004, 2007) yet, in reality, relatively little research has been undertaken into how and why tourists experience genocide sites.

The purpose of this paper is to address this gap in the literature. Drawing on exploratory research amongst international visitors to the Kigali Genocide Memorial, it builds on an earlier study of tourists' reported experience of genocide memorial sites in Rwanda (Sharpley, 2012). In so doing, it seeks to enhance knowledge and understanding of how tourists experience such sites, thereby contributing to the dark tourism literature more generally. The first task, however, is to consider the concept of genocide tourism within the broader context of the now established field of dark tourism before introducing the memorialisation of the Rwandan genocide in general and the Kigali Genocide Memorial in particular.

\section{Dark tourism and genocide memorial sites}

As is now widely recognised, and contradicting Lennon \& Foley's (2000: 11) assertion that it is an 'intimation of postmodernity', travel to and visiting 'dark sites', or so-called dark tourism, is by no means a new phenomenon. As long as people have been able to travel, they have been drawn, purposefully or otherwise, towards places or events that are associated in one way or another with death, disaster and suffering (Sharpley, 2009b). Moreover, there is little doubt that, over the last half century or so and commensurate with the remarkable growth in tourism more generally, dark tourism has become both widespread and diverse. Not only has there been a rapid increase in the provision of such attractions and experiences, including genocide sites, but there is also evidence of a greater willingness or desire on the part of tourists to visit dark attractions and, in particular, the sites of dark events. As Stone (2013: 307) notes in a recent review, 'the commodification of death for popular touristic consumption, whether in the guise of memorials and museums, visitor attractions, special events and exhibitions or specific tours, has become a focus for mainstream tourism providers'.

At the same time, the academic study of dark tourism can also no longer be considered a new phenomenon. The term 'dark tourism' itself was coined almost two decades ago (Foley \& Lennon, 1996), although the relationship between tourism and places of death and suffering had been the focus of earlier work, such as the interpretation of war sites (Uzell, 1989) and Rojek's (1993) conceptualisation of 'Black Spots', whilst a major theme in Tunbridge and Ashworth's (1996) exploration of dissonant heritage is the interpretation of the Holocaust at the concentration camps. Since then, and reflecting perhaps an alleged wider societal interest or fascination in death (Howarth, 2007; Walter, 2009), the increase in academic attention paid the concept of dark tourism has been such that it has become, in all likelihood one of the more popular fields of study within the tourism academy. Nevertheless, despite the greater scope and depth of research into the phenomenon, understanding of dark tourism remains relatively limited and theoretically fragile (Biran and Hyde, 2013: 191). Undoubtedly, this is due in part to the fact that dark tourism, typically defined as the 'act of travel to sites associated with death, suffering and the seemingly macabre' (Stone, 
2006), is a broad 'umbrella' concept that embraces an infinite variety of sites, attractions and experiences. Consequently, much attention has been devoted to the identification, labelling and management of different categories of dark attractions (that is, the research has predominantly adopted a supply perspective) whilst, until more recently, the significance of the consumption of (or demand for) dark tourism has enjoyed more limited academic scrutiny (but, see Raine, 2013; Stone \& Sharpley, 2008).

At the same time, the term dark tourism itself can be thought of as being 'unhelpful' (Sharpley \& Stone, 2009: 249). Not only has it become a product brand (Stone, 2013) exploited by the tourism industry and the popular media alike, but also from a consumption or behavioural perspective it may be considered a subjective, pejorative term, generalising 'dark' tourists as possessing a morbid fascination or curiosity in death, or engaging in voyeurism or schadenfreude. This may sometimes be the case; as Cole (1999: 114) argues, for example, 'there can be little doubt that an element of voyeurism is central to Holocaust tourism. Yet, there are evidently numerous instances where an interest in death may be minimal or non-existent, or the association with death may be of little relevance. Raine (2013), for example, in her study of visitors to burial grounds, identifies a continuum of purposes from 'devotion' (mourning / pilgrims), through 'experience' (morbid curiosity) and 'discovery' (information seekers / hobbyists) to 'incidental' (sightseers / recreationists). Thus, it has been suggested that the term 'dark tourism' should be abandoned as it 'may present an impediment to detailed and circumstantial analyses of tourist sites and performances' Bowman and Pezzullo (2009: 199).

It is not the purpose here to contribute to this debate. It suffices to suggest that dark tourism should be thought of not as a category of tourism site or attraction, nor as a specific form of tourism consumption. Rather, it should be seen as a context for exploring the relationship between the tourist and the (dark) site and, hence, for exploring how the tourist understands or confronts the death and suffering that the site signifies, represents or memorialises. Thus, as noted in the introduction to this paper, genocide sites in particular not only fulfil a variety of functions, from memorialisation / remembrance to education and reconciliation; a number have also become popular tourism destinations, including those in Rwanda. However, as the following section now considers briefly, with the exception of the Holocaust there is a paucity of research into tourism to genocide sites in general, and into the motivations and experiences of tourists who visit such sites in particular.

\section{'Genocide tourism'}

In his editorial on genocide tourism, Schaller (2007: 513) expresses surprise that an organised form of tourism based on genocide could exist: 'the idea seemed just too bizarre and macabre to be true'. Similarly, Beech (2009: 207) observes that the pairing of the words 'tourism' (usually signifying fun, escape, holidays and hedonism) and 'genocide' may seem unlikely. Nevertheless, what may be referred to as genocide tourism - that is, travel to and the experience of sites of or associated with genocide - is an identifiable (and flourishing) sector of the overall tourism market. For example, the site of the Auschwitz-Birkenau concentration camp in Poland, one of numerous sites associated directly or indirectly with the Holocaust, attracted 1.43 million visitors in 2012, a record number (Auschwitz-Birkenau 2014). In this case at least, therefore, it is also big business.

The Holocaust also features predominantly in the relevant literature. As Friedrich \& Johnston (2013) observe, research into the relationship between tourism and genocide focuses 'more on European events in the 
Second World War Jewish Holocaust than other acts of genocide', though not typically under the specific heading of 'genocide tourism' and more usually in the context of the management, development and interpretation of sites associated with the Holocaust. For example, a major theme in Tunbridge and Ashworth's (1996) exploration of dissonant heritage is the interpretation of the Holocaust at the concentration camps whilst Ashworth and Hartmann (2005) subsequently devote significant attention to the development of Holocaust related sites. Similarly, much of Lennon and Foley's (2000) seminal text focuses on sites related to the Holocaust, whilst Auschwitz in particular has proved to be a fruitful topic for academic research (Biran, Poria \& Oren, 2011; Cole 1999; Miles, 2002; Poria, 2007).

The Holocaust was also, of course, the first 'official' genocide. Although there is evidence throughout history of mass violence against particular groups, the term 'genocide' is relatively recent. It was first coined in 1944 by the Polish-Jewish lawyer, Raphael Lemkin, to describe the systematic destruction of European Jews and in 1948 was subsequently adopted and formally recognised as an international crime by the United $\mathrm{Na}$ tions Convention on the Prevention and Punishment of the Crime of Genocide (CPPCGG). Article 2 of this Convention defines genocide as '... acts committed with intent to destroy, in whole or in part, a national, ethnical, racial or religious group. This definition remains contentious, however, not least because it is not applied to the mass killing of people on either social or political grounds. Perhaps as a consequence, the Convention has been applied in only two cases since 1948: the Rwandan genocide in 1994 and the Srebrenica massacre of 1995.

This arguably restricted definition of genocide means that many events throughout history, from the mass killings of Armenians by Turkey during and after the First World War to the mass deaths that occurred during the Stalinist era in Russia (19291953) or the Cultural Revolution in China (1966-1971), are not formally recognised as genocides. Nevertheless, the systematic destruction of the Armenian population in the then Ottoman Empire is widely considered to be the first modern genocide. Also missing from the official list, though again widely thought of as genocide, is the death of over two million Cambodians during the four-year Khmer Rouge period in that country that was brought to wider public attention by the 1984 movie, The Killing Fields. Nevertheless, both Armenia and Cambodia have, according to Beech (2009), become genocide tourism destinations. In particular, the Tuol Sleng Museum of Genocide and the Cheung Ek Genocidal Centre in Cambodia are becoming increasingly popular attractions amongst the rapidly growing number of international tourists to that country.

Genocide tourism in Cambodia has also attracted increasing academic interest (Hughes, 2008; Williams, 2004), as have such sites related to the Balkan conflict (Johnston, 2011; Simic, 2008). However, in contrast to the relatively extensive literature on Holocaust tourism, research into tourism related to other more recent genocides is, as noted previously, limited. Moreover, in the case of both Holocaust tourism and tourism to other genocide sites more generally, little attention has been paid to the consumption of genocide tourism, or how tourists experience such places. Therefore, this paper now turns to genocide tourism in Rwanda, a subject which, with a few notable exceptions (Alluri, 2009; Friedrich \& Johnston, 2013; Grosspietsch, 2006; Hohenhaus, 2013) has been largely overlooked.

\section{Rwanda: the genocide and its memorialisation}

Although it was the shooting down of the President's aeroplane as it approached 
Kigali airport on the evening 6 April 1994 that sparked the Rwandan genocide, the subsequent horror and violence that was to engulf the country for one hundred days was not, as might be imagined, the spontaneous manifestation of tribal conflict. Rather, the roots of the genocide lay in the historic socio-economic distinctions between the majority Hutus and the minority Tutsis. Over centuries, the word 'Hutu' had evolved to describe farmers, servants or, more generally, those 'who did not come from an illustrious lineage' (Melvern 2009: 10). Conversely, Tutsis were the ruling elite; by the late 19th century, the monarchy and the King's army were predominantly Tutsi. Thus, as Melvern (2009: 12) summarises, 'In Rwanda, the words Hutu and Tutsi came to be used to define two groups linked through common experiences. The word Hutu would come to denote a peasant population, and the word Tutsi to denote overlords'.

This distinction was formalised by the Belgian colonial administration which introduced identity cards in 1932, an individual's classification often being based on wealth rather than on ethnicity or physical appearance. Consequently, some were identified as Tutsi simply on the basis of owning more than ten cows (KGM, 2004: 6). However, following the death of the king in 1959 and the subsequent election of the Parmehutu, a political party which sought the emancipation of the Hutu majority, 'Tutsis were increasingly harassed or killed and others were forced into exile' (Friedrich \& Johnston, 2013), whilst many joined the RFP based in neighbouring Uganda. Consequently, fearing a political and military challenge, from the 1970s the Habyarimana regime fostered an anti-Tutsi 'genocidal ideology' (KGM, 2004: 10) supported by the establishment of the Interahamwe, a nation-wide militia group, leading most to conclude that the 1994 genocide was deliberate, organised and rehearsed (Prunier, 2008).

The events leading up to the genocide, both within Rwanda and internationally, are complex, contested and beyond the scope of this paper (see Melvern, 2009; Prunier, 2008). However, following the end of the violence, numerous memorial sites were established around the country, usually on the site of mass graves and / or mass killings. Of these, four have been proposed by the Rwandan authorities for UNESCO World Heritage Site Status: the Kigali Genocide Memorial, and the Nyamata, Murambi and Bisesero memorials (de la Croix Tabaro, 2012). These are also amongst those memorials most commonly visited by international tourists, being significant for both the nature and representation of the atrocities they commemorate.

For example, The Murambi Memorial Centre is located in what was once a technical school near the town of Gikongoro, close to Butare in southern Rwanda. When the killing commenced in April 1994 over 65,000 Tutsis had fled to the school, believing they would be safe as French troops were stationed there. However, the troops allegedly left the Tutsis to defend themselves and, in the space of just three days, over 40,000 people were slaughtered.

The school has been developed as a memorial to the victims of the massacre and as a permanent exhibition of the genocide. Visitors to the Centre follow a pathway which leads them first to an exhibition describing the context of the genocide, then into socalled burial rooms. Here, the preserved bodies of some 800 victims, men, women and children, are laid out on tables for visitors to gaze upon.

Similarly, at the outbreak of the genocide many people from surrounding areas came to gather in the town of Nyamata, about 35 kilometres south of the capital, Kigali. The church and nearby houses belonging to the priests and sisters became havens for the frightened people who fled there hoping to escape death. They used the church as a refuge, thinking the militia would not enter and kill them in a place usually thought of 
as a sanctuary. However, according to the testimonies given by survivors, about 10,000 people were killed in and around the area of the church; though they had locked the iron door with a padlock to protect themselves, the door was broken down and all those in the church were massacred. Today in the church itself, bloodstains can be seen on the walls and the altar cloth, bullet holes can still be seen in the roof and the pews are strewn with the bloodied clothing of many of the victims. In the crypt are bones and skulls of some of those in died in the massacre, whilst outside the church visitors are able to enter mass graves where they can view the remains of hundreds of victims.

Figure 1: Entrance to the KGM (Photo: R. Sharpley)

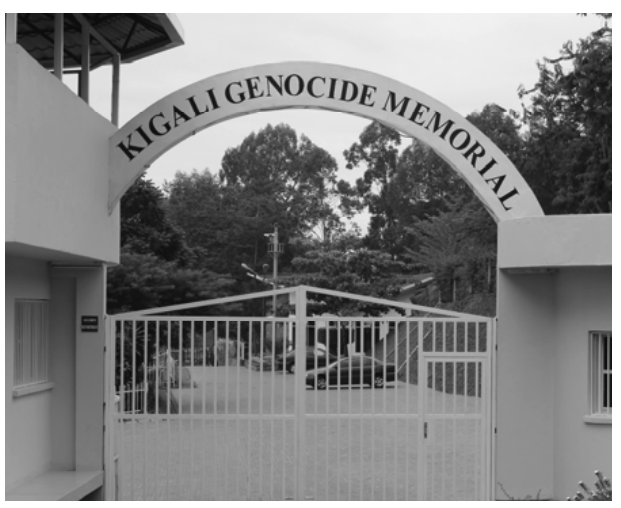

However, Rwanda's main memorial site is the Kigali Genocide Memorial (KGM). Located in the Gisozi district of the capital, the KGM is a joint venture between Kigali City Council and the UK-based Aegis Trust that campaigns against genocide and crimes against humanity. Constructed on the site where more than 250,000 victims of the genocide are buried, it was opened in April 2004 on the tenth anniversary of the Rwandan genocide, and is the best known and most visited memorial site in Rwanda, primarily because of its easy accessibility. It is primarily intended as a 'permanent memorial to those who fell victim to the genocide and serves as a place for people to grieve those they lost' (KGM, 2010), although it also functions as a centre for promoting peace and reconciliation more generally. There are three permanent exhibitions, the principal one documenting the 1994 genocide but, in addition, there is a children's memorial and an exhibition on the history of genocide worldwide. The memorial gardens include mass graves and a wall of names. Whilst intended primarily as a memorial, the centre also focuses on education:

'One of the principal reasons for the Centre's existence is to provide educational facilities. These are for a younger generation of Rwandan children some of whom may not remember the genocide, but whose lives are profoundly affected by it'. (KGMC, 2010).

Figure 2: School children at the KGM (Photo: R. Sharpley)

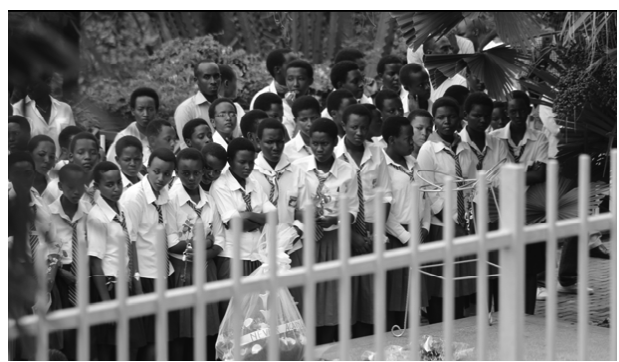

Thus, the KMG acts as a focus for commemorating and recognising the significance of the genocide to contemporary Rwanda, and is often visited by groups of school children (See Figure 2). However, it has also become one of Rwanda's more visited tourist attractions yet, as suggested above, little is known about the ways in which tourists experience the KGM or make sense of the event it commemorates, hence the exploratory research now discussed below. 


\section{The research}

As noted in the introduction, the research in this paper builds upon an earlier study of tourists' reported experience of genocide memorial sites in Rwanda, the purpose being to enhance knowledge and understanding of the meaning and significance of such experiences. Indeed, the earlier research identified how tourists reacted to the sites and, in particular, to the often graphic and shocking ways in which they represent the genocide. However, as a desk-based study an analysis of travel blogs, it was unable to elicit a more nuanced understanding of tourists' motives, expectations and response. Hence, further research, informed by the first study, was deemed necessary. Therefore, it is useful here to review briefly the outcomes of that study as background to the present research (for more detail, see Sharpley 2012).

\section{Initial research: tourists' reported experiences of genocide sites}

The initial study of international tourists' experiences of genocide sites in Rwanda drew on an analysis of a total thirty-five travel blogs posted by tourists who had visited on or more of four such sites: the Kigali Genocide Memorial, Murambi, Nyamata (all described above) and Ntarama, a church close to Nyamata that similarly witnessed the slaughter of some 5000 people. From the experiences reported in the travel blogs, a number of themes emerged under two distinct headings:

Motives: although the genocide sites have become an integral element of many tours to Rwanda, rather than visiting them simply 'because they are there' the majority of travel blogs implicitly revealed a positive desire on the part of tourists to experience the genocide sites to learn, to try to understand, to assuage guilt (that the rest of the world let it happen), but perhaps also to satisfy a personal need to be shocked, to be horrified, to be shaken out of complacency or to feel and share hope in humanity. One blog implied it is, in a sense, a tourist's duty to visit the sites: for one tourist, somehow you can't (and shouldn't) forget what happened here in 1994 whilst, for another, there are tourist attraction sites such as the Kigali memorial centre that is a must-visit for insights into the worst genocide in history.

Site experience: unsurprisingly, tourists' accounts of their visits to the genocide sites were both factual and emotional, with particular emphasis placed on their reactions to the graphic, uncompromising displays of victims' remains and belongings. Thus, a dominant theme was the intense feeling of shock, horror and revulsion experienced and described by most visitors to the genocide sites, not at the scale and inhumanity of the genocide but as a response to being confronted by innumerable bodies in mass graves, the preserved corpses laid out on tables, the piles of human bones and skulls and the bloodstained clothes of victims: When I reached the doorway, my entire body went cold. I froze, a few steps from the entrance. I could see, along the back wall of the church, stacks upon stacks of human skulls... I felt a wave of nausea come over me. Indeed, the sheer volume of skulls and bones on display had a dehumanising effect; the evident scale of the tragedy depersonalised it and the remains of any single person lost their individuality. As one blogger wrote: It is clear that the memorial has the intent to shock. It does. But at the same time, it is so macabre that it was hard to feel any grief when seeing the bodies. For another, the shock value was too great: it didn't make me reflect on the genocide as much as it made me offended by the showing of these bodies.

Consequently, a number of visitors revealed that they experienced greater emotion when viewing victims' personal items, such as clothing or children's schoolbooks: having the colourful but mouldy cloth of the victims hang over their bones increased the intensity of the grief and despair we felt for 
these people we had never met. More specifically, the images and stories of young victims on display in the KGM's children's gallery had the most powerful effect on tourists. In addition, the experience of the sites left many visitors feeling unable to comprehend the genocide whilst, for one, I felt like I didn't have the right to understand what I had seen, because there were stories that were being told that were not mine - and never will be mine, thus hinting at an inherent dilemma in genocide tourism more generally: whilst the victims of genocide may benefit from having their story told, what right do outsiders have to share that story with the victims? Nevertheless, many suggested that their visit to the genocide sites was a positive experience inasmuch as it engendered a feeling of hope: I have never felt such shame and anger... Yet, seeing how far the Rwandan people have come, I have never felt so much hope.

Overall, then, the initial research demonstrated that, far from being motivated by a voyeuristic desire to gaze on the tragedy of the genocide, not only do tourists visit the Rwandan sites for more positive reasons but also their responses to what they encounter point to a deeper emotional engagement with the sites. Nevertheless, much of the narrative in the travel blogs focused (perhaps unsurprisingly) on tourists' responses to the actual sites and, in particular, the often stark and shocking displays of human remains they were confronted with. Conversely, less was revealed about why and how they engaged with and responded to the event represented by the sites; that is, why they felt compelled to visit the sites and the extent to which they were able to confront not the victims' remains but the cause and manner of their violent death. Hence, further research was undertaken amongst international visitors to the KGM in order to address some of these unanswered questions. ${ }^{1}$

It should be noted that, at the time of writing, this research is ongoing. Hence, only preliminary results are discussed in this paper.

\section{Tourists' experiences of the Kigali Genocide Memorial Study methods}

The KGM was selected as an appropriate site for the research not only because it is the main (and most visited) memorial to the genocide but also because it offers a more diverse yet less morally challenging visitor experience than other genocide sites in Rwanda. In other words, although the KGM is located on the site of mass graves, visitors are not confronted with the bones, preserved remains or personal belongings of victims as at, for example, Murambi or Nyamata. Rather, although the scale of the violence is evident from the size of the concrete- covered mass graves, the visitor experience is constructed around the three permanent exhibitions described earlier in this paper: a self- (audio) guided tour around the story of the 1994 genocide, the history of genocide worldwide and the children's memorial. Thus, visitors are able to contemplate the genocide within a moral/ethical 'comfort zone' through reading narratives and gazing on (still often shocking) images, focusing their thoughts on the genocide as a whole rather than on their reactions to graphic collections of human remains. Moreover, the KGM is, implicitly, as much about the present and future of Rwanda as it is about the events of 1994.

The research was based upon a self-completion questionnaire distributed to randomly selected international visitors to the KGM. As previously noted, the overall purpose of the research was explicitly to elicit tourists' reasons for and responses to visiting the Memorial and the extent to which these reflect its objectives; implicitly, its purpose was to further challenge the claim that 'genocide' tourists are little more than voyeurs by exploring how the KGM, as a dark tourism site, mediates between the event it portrays and the tourist's own social reality. Thus, the questionnaire was constructed primarily around a 22-item, 5-point Likert scale which addresses a number of themes, including: 
- Reasons /motives for visiting the KGM

- Perceived role / significance of the KGM

- Understanding / knowledge of the genocide

- Experiences of / responses to the KGM itself

- Outcomes of the visit

The questionnaire also included a number of descriptive / categorisation questions as well as an open ended question offering respondents the opportunity to expand on their feelings / emotions having visited the Memorial.

\section{Research outcomes}

Of the thirty respondents completing the questionnaire in this initial phase of the research, all of whom were international visitors (ten were from the region, ten from north America, five from Europe and four from India), twelve were travelling for business purposes, four were visiting friends and relatives and fourteen were on holiday; it was the first time in Rwanda for eleven respondents, including all those on holiday, whilst the remainder had previously visited between two and four times, including those travelling for business purposes. Two thirds of respondents, including both business and leisure travellers, were on extended visits to East Africa and were planning to visit, or had visited, other countries in the region, including Uganda, Tanzania, Kenya and Burundi, whilst the remaining ten were visiting only Rwanda on this trip. This was the first visit to the KGM for nineteen respondents whilst the remaining eleven had previously visited the Memorial on at least one occasion.

In response to specific questions regarding intentions to visit other sites, sixteen respondents expressed the desire to also visit other genocide memorials (though the remaining fourteen did not wish to do so), reflecting the unexpected finding that almost half of the respondents also claimed that one of the main reasons for visiting Rwanda, including a number of those on business trips, was to enhance their knowledge and understanding of the genocide. Whilst no firm conclusions can be drawn from this given the relatively small sample, it suggests not only that, far from being an 'add on', a visit to the KGM has become a fundamental element or primary attraction of a visit to Rwanda, but also that the genocide is a defining characteristic of contemporary Rwanda. Conversely, just eight respondents indicated that they planned to visit the more 'traditional' attractions of Rwanda, specifically the country's national parks and the mountain gorillas. Again, no firm conclusions can be drawn from this - indeed, it is likely that in a larger sample with a higher proportion of western leisure visitors, different results would emerge. Nevertheless, from this study it would appear not only do visitors travel to Rwanda with the intent to experience at least one of the country's genocide memorial sites (typically the KGM), but also that doing so has become fundamental or essential to experiencing and engaging with contemporary Rwanda. Indeed, as now discussed, the results from the attitudinal survey of tourists' experiences of and responses to the KGM reveal positive motives and outcomes that challenge pejorative assumptions with respect to the consumption of dark / genocide tourism consumption.

As indicated above, the principal means of exploring visitors' perceptions and experiences of the KGM was a 22-item Likert scale based on five key themes. For convenience, the research outcomes are considered under each of these headings.

\section{i. Reasons /motives for visiting the KGM}

The purpose of this theme was to identify the extent to which tourists are positively motivated to visit the KGM as opposed to visiting it incidentally, 'just because it is 
there'. As can be seen from Table 1 below, 24 respondents (80\%) agreed / strongly agreed that they had decided prior to their trip to Rwanda that they would visit the KGM, indicating both knowledge of the Memorial's existence and a positive desire to do. The remaining six disagreed, suggesting either a more spontaneous decision to visit having arrived in Rwanda (reflecting Lennon and Foley's (2000) claim that most visits to dark tourism sites are likely to be serendipitous) or, perhaps, simply because it is included in a city tour. Indeed, eight respondents indicated that they visited the KGM 'just because it is here', contradicting to an extent the previous finding, though twenty (66\%) disagreed / strongly disagreed with this statement. Nevertheless, some ambivalence is in evidence, suggesting that some had previously decided to visit the KGN just because it was there - or 'famous for being famous' (Urry, 2002). However, in response to the statement I wanted to visit Kigali Genocide Memorial to learn about the 1994 genocide, the results are unequivocal with all respondents agreeing or strongly agreeing. When asked if they visited the KGM because of fascination in the genocide (a statement implying a more ghoulish / voyeuristic motive), fewer than half of respondents disagreed and ten confirmed that they were 'fascinated', though these results may reflect a less nuanced understanding of the word. Despite some inconsistencies within these results, however, this theme reveals overall a positive picture of tourists proactively deciding to visit the KGM primarily for learning about the genocide.

Table 1: Reasons / motives for visiting the KGM $(n=30)$

\begin{tabular}{|l|c|c|c|c|c|}
\hline & $\begin{array}{c}\mathbf{1} \\
\text { Strongly } \\
\text { disagree }\end{array}$ & $\begin{array}{c}\mathbf{2} \\
\text { Disagree }\end{array}$ & $\begin{array}{c}\mathbf{3} \\
\text { Neither } \\
\text { agree nor } \\
\text { disagree }\end{array}$ & $\begin{array}{c}\mathbf{4} \\
\text { Agree }\end{array}$ & $\begin{array}{c}\mathbf{5} \\
\text { Strongly } \\
\text { agree }\end{array}$ \\
\hline $\begin{array}{l}\text { Before coming to Rwanda, I had de- } \\
\text { cided that I would visit the Kigali } \\
\text { Genocide Memorial }\end{array}$ & & 6 & & 8 & 16 \\
\hline $\begin{array}{l}\text { I visited Kigali Genocide Memorial } \\
\text { Centre just because it is here }\end{array}$ & 12 & 8 & 2 & 8 & \\
\hline $\begin{array}{l}\text { I wanted to visit Kigali Genocide } \\
\text { Memorial to learn about the 1994 } \\
\text { genocide }\end{array}$ & & & & 10 & 20 \\
\hline $\begin{array}{l}\text { I wanted to visit the Kigali Genocide } \\
\text { Memorial as the Genocide fascinates } \\
\text { me }\end{array}$ & 14 & & 6 & 4 & 6 \\
\hline
\end{tabular}




\section{ii. Perceived role / significance of the KGM}

In this theme, the statements sought to identify the importance or significance of the KGM as perceived by tourists, pointing perhaps to their own reasons for visiting (see Table 2). The results are unsurprising and clear; not only did all respondents agree / strongly agree that all tourists should visit the Kigali Genocide Memorial whilst in Rwanda, but that they should do so because the genocide is considered to be part of Rwanda's modern history, a statement strongly agreed with by almost two thirds of respondents. Similarly, most agreed that the Memorial plays an important role in promoting peace and reconciliation, though some ambivalence is in evidence. Nevertheless, attitudes about the contemporary significance of the KGM are clearly evident; the genocide defines contemporary Rwanda and, hence, tourists should visit it to understand contemporary Rwanda.

Table 2: Perceived role / significance of the KGM

\begin{tabular}{|l|c|c|c|c|c|}
\hline & $\begin{array}{c}1 \\
\text { Strongly } \\
\text { disagree }\end{array}$ & $\begin{array}{c}\mathbf{2} \\
\text { Disagree }\end{array}$ & $\begin{array}{c}3 \\
\text { Neither } \\
\text { agree nor } \\
\text { disagree }\end{array}$ & $\begin{array}{c}\mathbf{4} \\
\text { Agree }\end{array}$ & $\begin{array}{c}\mathbf{5} \\
\text { Strongly } \\
\text { agree }\end{array}$ \\
\hline $\begin{array}{l}\text { I think all tourists should visit the } \\
\text { Kigali Genocide Memorial whilst } \\
\text { in Rwanda }\end{array}$ & & & & 14 & 16 \\
\hline $\begin{array}{l}\text { It's important to visit Kigali Geno- } \\
\text { cide Memorial as the Genocide is } \\
\text { part of Rwanda' modern history }\end{array}$ & & & & 11 & 19 \\
\hline $\begin{array}{l}\text { The Kigali Genocide Memorial } \\
\text { plays an important role in promo- } \\
\text { ting peace and reconciliation in } \\
\text { Rwanda }\end{array}$ & & & & 10 & 16 \\
\hline
\end{tabular}

iii. Understanding / knowledge of the genocide

In the initial (travel blog) research, a number of the narratives expressed difficulty in understanding how or why the genocide could have happened, particularly how such violence and cruelty could occur on such a scale. It is, perhaps, too much to expect anyone to 'understand' genocide, beyond the political or social forces described briefly earlier in this paper. Nevertheless, the statements this theme sought to address the issue of understanding, generating results that were undoubtedly predictable. Specifically, all but three respondents agreed / strongly agreed that, prior to travelling to the country, they had little or no understanding of how or why the genocide occurred; moreover, even though the official narrative of events attempts to explain it based upon the 'genocidal ideology' thesis, this only points to the deliberate campaign of 'ethnic cleansing. For all respondents, the human scale of the genocide and all that implies remains too large to understand. In this respect, perhaps, the KGM does not provide the answers that visitors seek; all respondents agreed that they wanted to or, indeed, needed to find out more about how and why the genocide occurred. At the same time, however, the ma- 
jority of respondents also felt that they were intruding on the tragedy of the genocide. In other words, the Rwandan genocide was a Rwandan tragedy for which outsiders have no right of understanding or explanation, pointing to an inherent contradiction with respect to the KGM as a tourist attraction.
Tourists are drawn there for a variety of reasons and, indeed, the KGM seeks to convey the message of the genocide to as wide an audience as possible yet, once they have experienced the memorial, tourists feel that they have intruded, that perhaps they should not have been there.

Table 3: Understanding / knowledge

of the genocide

\begin{tabular}{|l|c|c|c|c|c|}
\hline & $\begin{array}{c}1 \\
\text { Strongly } \\
\text { disagree }\end{array}$ & $\begin{array}{c}\mathbf{2} \\
\text { Disagree }\end{array}$ & $\begin{array}{c}\mathbf{3} \\
\text { Neither } \\
\text { agree nor } \\
\text { disagree }\end{array}$ & $\begin{array}{c}\mathbf{4} \\
\text { Agree }\end{array}$ & $\begin{array}{c}\mathbf{5} \\
\text { Strongly } \\
\text { agree }\end{array}$ \\
\hline $\begin{array}{l}\text { Before coming to Rwanda, I } \\
\text { didn't really understand how } \\
\text { or why the genocide happened }\end{array}$ & & 3 & & 11 & 16 \\
\hline $\begin{array}{l}\text { The scale of the genocide is too } \\
\text { big to understand }\end{array}$ & & & & 12 & 18 \\
\hline $\begin{array}{l}\text { Having visited the Kigali Ge- } \\
\text { nocide Memorial, I want / } \\
\text { need to understand more abo- } \\
\text { ut it. }\end{array}$ & & & & 13 & 12 \\
\hline $\begin{array}{l}\text { Ifeel I am intruding on the tra- } \\
\text { gedy of the genocide }\end{array}$ & & 4 & 4 & 10 & \\
\hline
\end{tabular}

\section{iv. Experiences of / responses to the KGM itself}

As noted earlier, a limitation of the initial study was that it focused primarily on tourists' reactions to the often horrific and challenging way in which some genocide sites are presented as memorials, particularly where large quantities of human remains are on display. Hence, the KGM was selected as an appropriate location for this research given its more 'benign' and, from a moral/ethical perspective, acceptable methods of representation and interpretation. Thus, the purpose of this theme was to reveal how tourists responded to the KGM as a memorial. Most surprisingly, perhaps, eighteen respondents agreed / agreed strongly that the story of the genocide at the Memorial is too graphic / too shocking for tourists, though just six respondents strongly agreed; twelve disagreed or were ambivalent, perhaps because the very purpose of the KGM is to raise awareness of the horror of the genocide. Nevertheless, all respondents agreed / agreed strongly that My visit to the Kigali Memorial centre has shocked me; assuming that it is the story, rather than the manner in which it presented, that is found to be shocking, this differs from the earlier study in which it was the displays of bones / human remains that were so distressing for visitors. 
Table 4: Experiences of / responses to the KGM itself

\begin{tabular}{|l|c|c|c|c|c|}
\hline & $\begin{array}{c}\mathbf{1} \\
\text { Strongly } \\
\text { disagree }\end{array}$ & $\begin{array}{c}\mathbf{2} \\
\text { Disagree }\end{array}$ & $\begin{array}{c}\mathbf{3} \\
\text { Neither } \\
\text { agree nor } \\
\text { disagree }\end{array}$ & $\begin{array}{c}\mathbf{4} \\
\text { Agree }\end{array}$ & $\begin{array}{c}\mathbf{5} \\
\text { Strongly } \\
\text { agree }\end{array}$ \\
\hline $\begin{array}{l}\text { I was nervous about visiting } \\
\text { the Kigali Genocide Memorial } \\
\text { because of what I might see }\end{array}$ & & 4 & 2 & 16 & 8 \\
\hline $\begin{array}{l}\text { The Kigali Genocide Memorial } \\
\text { powerfully conveys the horror } \\
\text { of the genocide }\end{array}$ & & & & 8 & 22 \\
\hline $\begin{array}{l}\text { My visit to the Kigali Memori- } \\
\text { al centre has shocked me }\end{array}$ & & & & 12 & 18 \\
\hline $\begin{array}{l}\text { Having visited the Kigali Gen- } \\
\text { ocide Memorial, I feel guilty } \\
\text { that the West allowed the gen- } \\
\text { ocide to happen }\end{array}$ & 2 & 3 & 3 & 10 & 14 \\
\hline $\begin{array}{l}\text { It is the individual stories of } \\
\text { children that most convey the } \\
\text { horror of the genocide }\end{array}$ & & 8 & 4 & 12 & 6 \\
\hline $\begin{array}{l}\text { The story of the genocide at the } \\
\text { Memorial is too graphic / too } \\
\text { shocking for tourists }\end{array}$ & & & & 4 & 20 \\
\hline
\end{tabular}

The great majority (twenty-two respondents) strongly agreed that the KGM conveys the horror of the genocide powerfully and effectively whilst, confirming the results of the earlier study, it was the individual stories of children that most convey the horror of the genocide for twenty-four respondents. However, three disagreed or were ambivalent about this statement. Similarly, the agreement of twenty-four respondents to the statement Having visited the Kigali Genocide Memorial, I feel guilty that the West allowed the genocide to happen also reflected the some of the narratives analysed in the earlier study. Thus, overall visitors were evidently justified in their majority agreement that they felt nervous about what they might encounter at the KGM; they found the story to be shocking but, at the same time, they had begun to understand the horror of the genocide, particularly when conveyed through graphic descriptions of the violence against young children. For some, it was too shocking, as revealed in responses to the open ended question. For example, one respondent, encapsulating the views of a number of others, wrote:

Too shocked. I would not have believed that human beings can be this brutal to their own brothers and sisters. Can anyone do this/ Are we human? Even animals will not behave this way. I would like to know how the killers think about what they did twenty years ago... 
At the same time, many respondents recognised the message that is conveyed by the horrific story of the genocide:

It is hard to see all these stories and bad things, but it... sometimes helps us to understand how we are responsible for everything that happens around us. And:

[We] should hope that more people from other countries can visit this site. They would learn a lesson to avoid a repeat of such in future.

In other words, a number of respondents responded to their visit to the KGM by feeling a sense of guilt at the inaction of the rest of the world to prevent the genocide:

I was saddened by the fact that the UN, the western countries did nothing to prevent or stop this awful event. I am shocked that some countries actually contributed to this horror.

\section{v. Outcomes of the visit}

The final theme in the questionnaire focused on the attitudes of tourists with regards to their visit to the KGM overall; specifically, it sought to identify whether it had been a positive or negative experience. The results suggest that the KGM is achieving its objectives inasmuch as the great majority of respondents (twenty-seven) agree / strongly agree that their visit had made the horror of the Genocide more real to me; that is, although all visitors would have been aware of the genocide and, perhaps, even remembered witnessing it at the time through images on television or in newspaper reports, visiting the KGM had rendered the genocide more 'real' to them. It was no longer something viewed from a distance through a TV screen.

Table 5: Outcomes of the visit

\begin{tabular}{|l|c|c|c|c|c|}
\hline & $\begin{array}{c}1 \\
\text { Strongly } \\
\text { disagree }\end{array}$ & $\begin{array}{c}\mathbf{2} \\
\text { Disagree }\end{array}$ & $\begin{array}{c}3 \\
\text { Neither } \\
\text { agree nor } \\
\text { disagree }\end{array}$ & $\begin{array}{c}\mathbf{4} \\
\text { Agree }\end{array}$ & $\begin{array}{c}\text { Strongly } \\
\text { agree }\end{array}$ \\
\hline $\begin{array}{l}\text { My visit to the Genocide Me- } \\
\text { morial Centre has helped me } \\
\text { to understand what Rwanda } \\
\text { is today }\end{array}$ & & & & 11 & 19 \\
\hline $\begin{array}{l}\text { My visit to the Kigali Genocide } \\
\text { Memorial has made the hor- } \\
\text { ror of the Genocide more real } \\
\text { to me }\end{array}$ & 1 & 3 & 3 & 7 & 20 \\
\hline $\begin{array}{l}\text { I am pleased that I have had } \\
\text { the opportunity to visit the Ki- } \\
\text { gali Genocide Memorial }\end{array}$ & & 3 & 3 & 10 & 14 \\
\hline $\begin{array}{l}\text { Visiting the Kigali Genocide } \\
\text { Memorial has been a positive } \\
\text { experience }\end{array}$ & 1 & 3 & & & 27 \\
\hline $\begin{array}{l}\text { Following my visit, my main } \\
\text { feeling is one of hope for the } \\
\text { future of Rwanda }\end{array}$ & & & & & \\
\hline
\end{tabular}


Moreover, all respondents indicated that their experience of the KGM helped them to understand contemporary Rwanda, how the genocide had shaped the country as it is today, whilst with one exception, all respondents were also pleased that they had had the opportunity to visit the memorial. Nevertheless, some were uncertain whether their experience of the KGM had been a positive one; four disagreed that it had been positive whilst one neither agreed nor disagreed. The reason for this is unclear, though it is likely that the knowledge they had gained of the genocide had left them with negative feelings. A minority of respondents (three) also did not feel hopeful for the future of Rwanda, perhaps reflecting the view that tensions between social groups in Rwanda remained, albeit hidden by an apparent national unity. Conversely, he remaining twenty-seven respondents all strongly agreed that, following their visit to the KGM, their main feeling was one of hope for the future of Rwanda. They thus confirmed the same sense of hope for the county as reported in the narrative analysed in the initial research.

\section{Conclusion}

As noted in the introduction, this paper set out to enhance knowledge and understanding of how tourists experience genocide sites in Rwanda and, in particular, to identify the extent to which they engage at an emotional level with sites that represent, interpret and commemorate violent death on a mass scale. In so doing, it sought to challenge the (unsubstantiated) claim by some that tourists, as outsiders, cannot begin to understand such events or take positive meaning from visiting genocide memorial sites and, therefore cannot be considered to be anything but voyeurs. The evidence from both studies reported here demonstrates unequivocally that this is not the case, that tourists undertake their vis- its with positive, meaningful intent (albeit with trepidation) and that, almost without exception, find it a challenging, powerfully emotional yet, ultimately, rewarding experience in that they begin to grasp the horror and suffering of the genocide and, indeed, leave with the desire to learn more about it. Specifically, whilst the initial study revealed some confusion on the part of tourists, their focus on or contemplation of the genocide being blurred by the graphic display of human remains and belongings at some sites, the follow up survey, though limited in terms of numbers of respondents, revealed clear outcomes: premeditated desires to visit the KGM founded on a need to learn about the genocide; a belief that all tourists in Rwanda should visit the KGM, suggesting it is the most important experience to be had in the country; a sense of horror about the genocide combined with guilt that the world stood by and watched; the belief that the genocide was too big to understand; and, that visiting the KGM left them with a sense of hope, that Rwanda had not only survived but will continue to survive and move on. Thus, it is evident that the KGM, as a 'dark' tourism site, mediates between the events it represents and commemorates and this who visit, whether Rwandans or international tourists. As such, as reinforces the conclusion, stated elsewhere, that dark tourism is as much about life and the living as it is about death (Sharpley \& Stone 2009).

\section{References}

AEO (2014) Rwanda. African Economic Outlook. Available at: http://www.africaneconomicoutlook.org/en/countries/east-africa/rwanda/ (Accessed 10 January 2014)

Alluri, R. (2009) The Role of Tourism in PostConflict Peacebuilding in Rwanda. Working Paper. Bern, Switzerland: Swisspeace.

Auschwitz-Birkenau (2014) Auschwitz Memorial in 2012: Undiminished Interest of the 
World. Available at: http://en.auschwitz. org $/ \mathrm{m} /$ index.php?option=com_content $\&$ task $=$ view\&id $=1073 \&$ Itemid $=8$ (Accessed 20 January 2014)

Beech, J. (2009) Genocide tourism. In R. Sharpley \& P. Stone (Eds.), The Darker Side of Travel: The Theory and Practice of Dark Tourism. Bristol: Channel View Publications, 207-223.

Bowman, M. \& Pezzullo, P. (2009) What's so 'dark' about 'dark tourism'?: Death, tours, and performance. Tourist Studies 9(3), 187-202.

Biran, A. \& Hyde, K. (2013) New perspectives on dark tourism. International Journal of Culture, Tourism and Hospitality Research 7(3), 191-198.

Buda, D. \& McIntosh, A. (2013) Dark tourism and voyeurism: tourist arrested for 'spying' in Iran. International Journal of Culture, Tourism and Hospitality Research 7(3), 214-226.

Cohen, E. (2011). Educational dark tourism at an populo site: The holocaust museum in Jerusalem. Annals of Tourism Research, 38(1), 193-209.

Cole, T. (1999) Selling the Holocaust. From Auschwitz to Schindler: How history is Bought, Packaged and Sold. New York: Routledge.

Cook, S. (2006). Genocide in Cambodia and Rwanda: New Perspectives. New Brunswick, NJ: Transaction Publishers.

de la Croix Tabaro, J. (2012) Rwanda: Genocide memorials proposed as world heritage.

http://focus.rw/wp/2012/07/genocide-memorials-proposed-as-world-heritage (Accessed 22 January 2014)

Foley, M. \& Lennon, J. (1996) JFK and dark tourism: A fascination with assassination. International Journal of Heritage Studies 2(4), 198-211.

Friedrich, M. \& Johnston, T. (2013) Beauty versus tragedy: thanatourism and the memorialisation of the 1994 Rwandan Genocide. Journal of Tourism and Cultural Change. DOI: $10.1080 / 14766825.2013 .852565$.
Grosspietsch, M. (2006) Perceived and projected images of Rwanda: Visitor and international tour operator perspectives. Tourism Management 27(2), 225-234.

Hohenhaus, P. (2013) Commemorating and commodifying the Rwandan genocide: Memorial sites in a politically difficult context. In E. Frew \& L. White (Eds.), Dark Tourism and Place Identity. Abingdon: Routledge, 142-155.

Howarth, G. (2007) Death and Dying: A Sociological Introduction. Cambridge: Polity Press.

Hughes, R. (2008) Dutiful tourism: Encountering the Cambodian genocide. Asia $\mathrm{Pa}$ cific Viewpoint 49(3), 318-330.

Johnston, T. (2011) Thanatourism and commodification of space in post-war Croatia and Bosnia. In R. Sharpley and P. Stone (eds) Tourist Experience: Contemporary Perspectives. London: Routledge, 43-55.

KGM (2004) Jenoside: Kigali Memorial Centre. Kigali Genocide Memorial / Aegis Trust.

Lennon, J \& Foley, M. (2000) Dark Tourism: the attraction of death and disaster. London: Continuum.

Lisle, D. (2004) Gazing at Ground Zero: tourism, voyeurism and spectacle. Journal for Cultural Research 8(1), 3-21.

Lisle, D. (2007) Defending voyeurism: dark tourism and the problem of global security. In P. Burns \& M. Novelli (Eds.), Tourism and Politics: Global Frameworks and Local Realities. Oxford: Elsevier, 336-346.

Melvern, L. (2009) A People Betrayed: The role of the West in Rwanda's Genocide. London: Zed Books.

Prunier, G. (2008) The Rwandan Crisis: History of a Genocide ( $\left.2^{\text {nd }} \mathrm{Edn}\right)$. London: C. Hurst \& Co.

Raine, R. (2013) A dark tourist spectrum. . International Journal of Culture, Tourism and Hospitality Research 7(3), 242-256.

RDB (2014a) Highlights of tourist arrivals in Rwanda: 2010. Rwanda Development Board. http://www.rdb.rw/fileadmin/user_upload/ Documents/tourism\%20conservation/Ar- 
rival_Statistics_2010_Jan-Dec.pdf(accessed 10 January 2014)

RDB (2014b) Welcome to Rwanda. Rwanda Development Board. http://www.rwandatourism.com/ (accessed 10 January 2014).

Rojek, C. (1993) Ways of Escape. Basingstoke: Macmillan.

Schaller, D. (2007) From the editors: genocide tourism: educational value or voyeurism? Journal of Genocide Research 9(4), 513-515.

Sharpley, R. (2009a) Dark tourism and political ideology: towards a governance model. In R. Sharpley \& P. Stone (Eds.), The Darker Side of Travel: The Theory and Practice of Dark Tourism. Bristol: Channel View Publications, 145-163.

Sharpley, R. (2009b) Shedding light on dark tourism. In R. Sharpley and P. Stone (Eds.), The Darker Side of Travel: The Theory and Practice of Dark Tourism. Bristol: Channel View Publications, 3-22.

Sharpley, R. (2012) Towards an understanding 'genocide tourism': an analysis of visitors' accounts of their experience of recent genocide sites. In R. Sharpley \& P. Stone (Eds.), The Contemporary Tourist Experience: Concepts \& Consequences. Abingdon: Routledge, 95-109.

Sharpley, R. \& Stone, P. (2009) Life, death and dark tourism: future research directions and concluding comments. In In R. Sharpley and P. Stone (Eds.), The Darker Side of Travel: The Theory and Practice of Dark Tourism. Bristol: Channel View Publications, 247-251.

Simic, O. (2008) A tour to the site of genocide: Mothers, bones and borders. Jour- nal of International Women's Studies 9(3), 320-330.

Stone, P. (2006) A dark tourism spectrum; towards a typology of death and macabre related tourist sites, attractions and exhibitions. Tourism: An Interdisciplinary Journal 54(2), 145-160.

Stone, P. (2013) Dark tourism scholarship: a critical review. International Journal of Culture, Tourism and Hospitality Research 7(3), 307-318.

Stone, P. \& Sharpley, R. (2008) Consuming dark tourism: a thanatological perspective. Annals of Tourism Research 35(2), 574595.

Tunbridge, J. and Ashworth, G. (1996) Dissonant Heritage: Managing the Past as a Resource in Conflict. Chichester: John Wiley \& Sons.

Uzzell, D. (1989) The hot interpretation of war and conflict. In D. Uzell (ed) Heritage Interpretation, Vol. I. The Natural and Built Environment. London: Bellhaven Press, 33-47.

Walter, T. (2009) Dark tourism: Mediating between the dead and the living. In R. Sharpley \& P.Stone (Eds.), The Darker Side of Travel: The Theory and Practice of Dark Tourism. Bristol: Channel View Publications, 39-55.

Williams, P. (2004) Witnessing genocide: vigilance and remembrance at Tuol Sleng and Choeng Ek. Holocaust and Genocide Studies 18(2), 234-255.

Williams, P. (2007) Memorial Museums: The Global Rush to Commemorate Atrocities. Oxford: Berg. 